\title{
Agronomic factors affect powdery scab of potato and amounts of Spongospora subterranea DNA in soil
}

\author{
Farhat A. Shah • Richard E. Falloon - Ruth C. Butler • \\ Ros A. Lister • Steve M. Thomas • Denis Curtin
}

Received: 14 April 2014 / Accepted: 5 September 2014 / Published online: 17 September 2014

(C) Australasian Plant Pathology Society Inc. 2014

\begin{abstract}
Severe powdery scab (caused by Spongospora subterranea) occurred in potato tubers harvested from a field trial, which measured effects of agronomic treatments (nitrogen fertiliser rates, irrigation intensities, previous crop rotations) on potato yields. Nitrogen application $\left(400 \mathrm{~kg} \mathrm{~N} \mathrm{ha}^{-1}\right)$ increased weight of tubers per plant by $38 \%$. Incidence and/or severity of powdery scab were increased by nitrogen applications. Measurements of S. subterranea DNA in soil at harvest generally reflected the severity of powdery scab in harvested tubers. Amounts of DNA were greater after nitrogen application than without nitrogen fertiliser, less after "optimum" irrigation than "low" irrigation, and greater after a potato/ wheat rotation than after potato/pea. The field trial area was used for two further growing seasons (without application of treatments) to determine if pre-planting measurements of Spongospora DNA in soil could predict powdery scab in harvested potatoes. The disease generally decreased during the next two growing seasons, and effects of the different agronomic treatments on powdery scab had disappeared by the second season. However, the greater amounts of pathogen DNA in soil in plots where nitrogen had been applied than where no fertiliser was used continued for the two following growing seasons. Relationships between amounts of preplanting S. subterranea DNA in soil and powdery scab in subsequently harvested tubers were weak in the second growing season, and non-existent in the third. These results demonstrate that agronomic treatments (particularly nitrogen) can
\end{abstract}

F. A. Shah $(\bowtie) \cdot$ R. E. Falloon · R. C. Butler $\cdot$ R. A. Lister

S. M. Thomas $\cdot$ D. Curtin

The New Zealand Institute for Plant \& Food Research Limited, PB

4704, 8140 Christchurch, New Zealand

e-mail: farhat.shah@plantandfood.co.nz

R. E. Falloon

Bio-Protection Research Centre, Lincoln University, PO Box 84, 7647 Lincoln, New Zealand increase severity of powdery scab in harvested tubers. Furthermore, pre-planting measurements of pathogen DNA in soil did not give good predictions of the incidence or severity of powdery scab in harvested potatoes.

Keywords Nitrogen fertiliser - Soil moisture - Crop rotation · Disease prediction

\section{Introduction}

Powdery scab of potato tubers (Solanum tuberosum) is an important disease that is widespread in potato growing countries throughout the world. It is caused by the Cercozoan Spongospora subterranea f. sp. subterranea, a biotrophic soilborne pathogen of intensively managed potato crops (Merz and Falloon 2010). Spongospora subterranea is also the vector of the Potato mop-top virus, another economically important pathogen of potato (Kirk 2008). Lesions on tubers caused by $S$. subterranea reduce their quality and value as seed potatoes, and as tubers for fresh market sale or processing. Furthermore, recent research suggests that root infections by the pathogen have the potential to reduce host growth and productivity (Shah et al. 2012). Information on powdery scab and S. subterranea, including effects of agronomic factors on the disease and pathogen, has been reviewed by Harrison et al. (1997) and Merz and Falloon (2010).

Severe powdery scab was observed on samples of potato tubers harvested from a large field trial, where potatoes were grown and effects of different agronomic treatments on potato yields were assessed (Thomas et al. 2012). Those treatments included different rates of nitrogen fertiliser application, different intensities of irrigation, and different previous cropping histories. Detailed assessments of tuber yield parameters and incidence and severity of powdery scab on tubers were carried out for potatoes harvested from each of the 96 plots in the trial. 
These showed that there were distinct between-plot differences in disease and yield parameters, so the data were examined to determine if these differences were related to the agronomic treatments applied in the trial, or to amounts of S. subterranea DNA in the soil at the time of harvest.

The trial area was subsequently monitored for the following two growing seasons, without further application of the agronomic treatments. In each of these seasons, amounts of S. subterranea DNA in soil were measured in each trial plot in spring, and seed potatoes of a powdery scab-susceptible cultivar were then planted into each plot. Powdery scab incidence and severity were measured in the resulting harvested tubers at crop maturity. This study aimed, firstly, to quantify the effects of important agronomic factors (nitrogen fertiliser rates, irrigation intensity, previous crop) on powdery scab and amounts of pathogen inoculum in soil, and secondly, to assess if amounts of S. subterranea DNA in soil before planting can give reliable indications of powdery scab incidence or severity in harvested potato tubers.

\section{Materials and methods}

\section{Agronomic treatment trial (2006/07 growing season)}

This field trial was established in October 2006, on a Templeton silt loam soil, near Lincoln, Canterbury, New Zealand (lat $43^{\circ} 40^{\prime} \mathrm{S}$, long $172^{\circ} 28^{\prime} \mathrm{E}$; mean annual air temperature $11.4^{\circ} \mathrm{C}$; mean annual rainfall $897 \mathrm{~mm}$ ). Twelve treatments were applied in the trial, which was of split-split plot design with eight replicates (total of 96 plots), covering a total area of $0.36 \mathrm{ha}$. The main plots were laid out in randomised blocks. Each split-split plot was $5 \mathrm{~m}$ long and consisted of six rows of planted seed potato tubers ('Ranger Russet': moderately resistant to powdery scab; Falloon et al. 2003), with $0.75 \mathrm{~m}$ spacing between rows, and approx. $0.3 \mathrm{~m}$ spacing between planted seed tubers within the rows. The trial treatments were:

- two different annual crop rotation cycles during the previous two growing seasons (potatoes followed by wheat or potatoes followed by peas), applied to the main plots $(10 \mathrm{~m} \times 15 \mathrm{~m})$;

- two soil moisture regimes ("low", $90 \mathrm{~mm}$ deficit irrigated to $30 \mathrm{~mm}$ deficit; or "optimum", $60 \mathrm{~mm}$ deficit irrigated to $30 \mathrm{~mm}$ deficit), applied to the split plots (six rows $\times 15 \mathrm{~m}$ ); and

- three treatments of nitrogen fertiliser (calcium ammonium nitrate), equivalent to 0,200 or $400 \mathrm{~kg} \mathrm{~N} \mathrm{ha}^{-1}$, applied to the split-split plots (six rows $\times 5 \mathrm{~m}$ ).

At crop maturity (12 March, 2007), all potato tubers from a $2 \mathrm{~m}$ length of row (eight plants) from the centre of each of the
96 plots were hand harvested, taken to a field laboratory and washed free of soil. Number of tubers and total weight of tubers were recorded for each plot. The tubers were each assessed for powdery scab severity using a five point scale (truncated from the scale presented by Falloon et al. 1995: see Fig. 3) as follows: $0=$ no disease; $1=$ less than $5 \%$ tuber surface area affected; $2=5-20 \%$ tuber surface area affected; $3=20-46 \%$ tuber surface area affected; and $4=$ more than $46 \%$ tuber surface area affected. The number and weight of tubers with each score were recorded, and incidence of powdery scab (proportion of tubers with the disease) was determined. Soil samples (ten to 15 , depth approx. $20 \mathrm{~cm}$ ) were taken from the harvested area of each plot. These samples were mixed, and 300-500 g sub-samples were dried at $40^{\circ} \mathrm{C}$ for $24 \mathrm{~h}$, and were then sent to the South Australian Research and Development Institute for quantification of S. subterranea DNA, using specialised soil extraction and quantitative polymerase chain reaction (qPCR) techniques (Ophel-Keller et al. 2008).

Assessments in two subsequent growing seasons (2007/08 and 2008/09)

The trial area was cultivated using a tractor-mounted rotary hoe, and sown into wheat (Triticum aestivum) as a winter crop in late autumn (May 2007). The resulting green crop was incorporated into the soil, and the trial area was prepared for potato planting, again with rotary hoe cultivation. Small plots of potatoes (see below) were planted into the 96 plots in spring (October 2007), and the resulting tubers were harvested in autumn (April 2008). After cultivation, the trial area was then sown in annual ryegrass (Lolium multiflorum) in late autumn (May 2008). The resulting green crop was harvested and removed. The trial area was again prepared for potato planting in spring (October 2008), and 96 small plots of potatoes were established (see below, and Fig. 1).

For each of the 96 plots in the trial, one $2 \mathrm{~m}$ row (2007) or two similar rows (2008) were marked in the centre of the plot. Pre-planting soil samples were taken from each row for

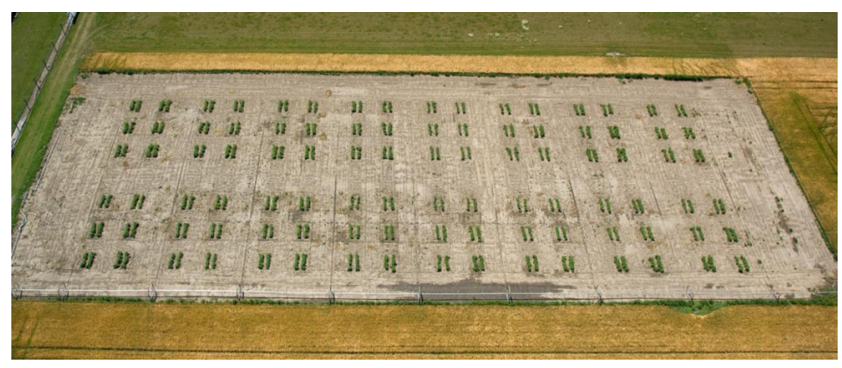

Fig. 1 Aerial view of the Spongospora subterranea infested field trial area ( 0.36 ha) during the $2008 / 09$ growing season. Ninety-six plots were each planted with two rows of eight seed potatoes, giving 16 potato plants in each plot 
S. subterranea DNA analyses (sampling and analysis described above). Eight seed tubers ('Iwa', very susceptible to powdery scab: Falloon et al. 2003), free of surface diseases, were planted in each row at $0.3 \mathrm{~m}$ spacing. The remaining area of each plot was left fallow (Fig. 1). The trial area was irrigated throughout each growing season (approx. $50 \mathrm{~mm}$ water each 10-14 days), and no further fertiliser applications were applied to the trial plots. The potato plants were grown to maturity and then harvested in autumn (7 April 2008; 30 and 31 March 2009). All harvested tubers were washed, counted, weighed and assessed for powdery scab incidence and severity. Postharvest soil samples were taken from each row immediately after harvest for $S$. subterranea DNA analyses (as described above).

Statistical analyses

The mean powdery scab score (severity) per plot was calculated as the mean of scores for all the tubers in the harvested rows, and powdery scab incidence was determined as the percentage of tubers showing symptoms (score greater than 0 ) per row. Tuber yields, powdery scab severity scores and soil DNA were initially assessed for field spatial trends and for the importance of the split-plot structure, using mixed model analyses (fitted with restricted maximum likelihood (REML: Payne et al. 2012). This analysis showed that spatial trends and the split-plot structure were largely unimportant, and so no adjustment was made for these in the subsequent analyses. Tuber yields, powdery scab severity scores and soil Spongospora DNA data were analysed with analysis of variance, with DNA values first transformed $\left(\log _{10}\right)$ to stabilise variances. Powdery scab incidence data (percent tubers affected) were analysed with a binomial generalised linear model (McCullagh and Nelder 1989). Relationships between soil S. subterranea DNA at the time of harvest in the $2007 / 08$ growing season and powdery scab incidence and severity scores on the harvested tubers were explored graphically, and linear correlations (Pearson's r) were calculated. Relationships between soil $S$. subterranea DNA and tuber powdery scab were examined in the 2007/08 and 2008/09 growing seasons, using data for soil DNA sampled prior to potato planting. All statistical analyses of the recorded data were carried out using GenStat (GenStat Committee 2008). Mean powdery scab severity scores were also converted to proportions of tuber surface affected by the disease, using appropriate arithmetic calculations.

\section{Results}

Tuber yields

Tuber yield data are summarised in Fig. 2. Yield per plant was generally least from the 2007 harvest (from 'Ranger Russet'), and greater from the two subsequent harvests in 2008 and 2009 (from 'Iwa').

\section{Agronomic treatment trial (2006/07 growing season)}

Tuber yields in 2007 were affected by the different nitrogen regimes. Mean weight of tubers per plant was least $(0.50 \mathrm{~kg} /$ plant) in the absence of added nitrogen fertiliser, intermediate $(0.63 \mathrm{~kg} / \mathrm{plant})$ from $200 \mathrm{~kg} \mathrm{~N} \mathrm{ha}^{-1}$, and greatest $(0.69 \mathrm{~kg} /$ plant; $+38 \%)$ from $400 \mathrm{~kg} \mathrm{~N} \mathrm{ha}^{-1}(P<0.001)$. Nitrogen and rotation effects were independent ( $P>0.2$ for all interactions). Overall, previous crop rotation significantly affected yield per plant $(P=0.046)$, with on average $47 \mathrm{~g}$ per plant more from the potato/wheat rotation than from the potato/pea rotation. Yields were not substantially affected by the different soil moisture

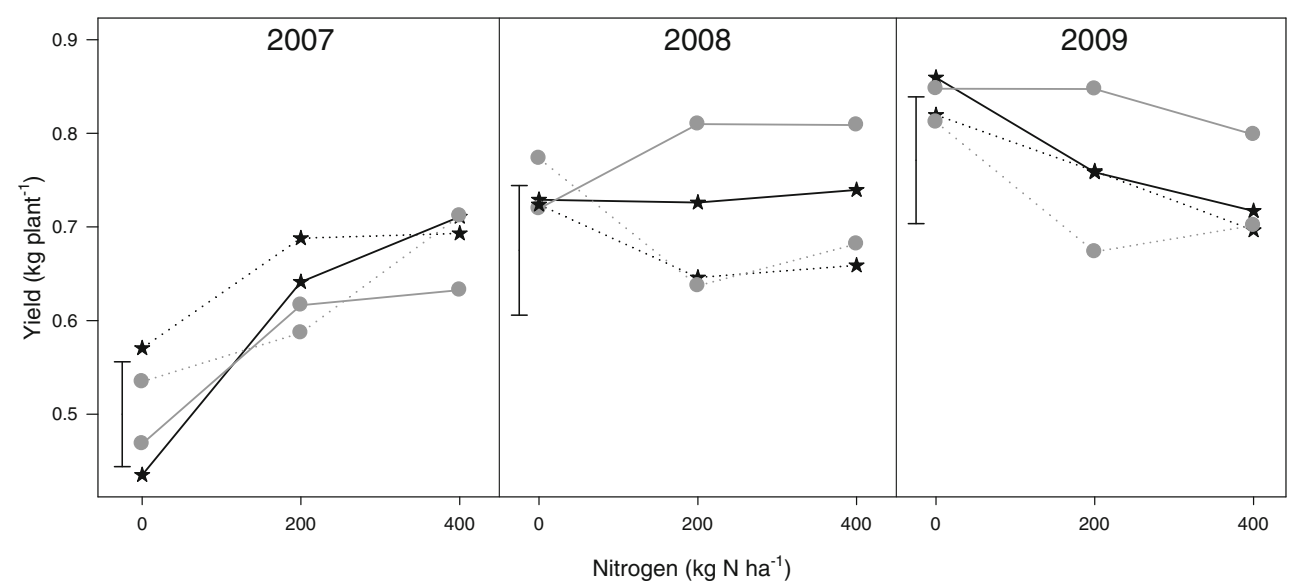

Fig. 2 Mean yields of potato tubers harvested from field plots in 2007 ('Ranger Russet'), 2008 and 2009 ('Iwa'). Treatments of different amounts of nitrogen fertiliser, watering regimes and previous crop rotations were applied to the plots in the $2006 / 07$ growing season. $\star$ :

optimum watering; $\bullet$ : low watering. Solid lines: potato/pea rotation; dotted lines: potato/wheat rotation. Bars are LSDs $(P<0.05$; $\mathrm{df}=77)$. Note: the 2008 and 2009 data are presented in relation to nitrogen treatments applied in the 2006/07 season 
regimes ( $P=0.176)$, probably because rainfall $(230 \mathrm{~mm})$ was evenly distributed during the 2006/07 growing season, maintaining the soil moisture content at adequate levels for potato production.

\section{7/08 growing season}

For the 2008 harvest, mean weight of tubers per plant (Fig. 2) was greater $(P=0.02)$ from the potato/pea (/potato) rotation (mean $=0.76 \mathrm{~kg} / \mathrm{plant}$ ) than from the potato/wheat (/potato) rotation $(0.69 \mathrm{~kg} / \mathrm{plant})$. The different nitrogen treatments and moisture regimes (applied in the 2006/07 season) did not substantially affect tuber yields (overall mean $=0.72 \mathrm{~kg} / \mathrm{plant}$; $P>0.05$ for all effects, other than the rotation effect).

\section{8/09 growing season}

At the 2009 harvest, mean weight of tubers per plant (Fig. 2) was again greater $(P=0.03)$ from the potato/pea (/potato/potato) rotation (mean $=0.80 \mathrm{~kg} / \mathrm{plant}$ ) than from the potato/ wheat (/potato/potato) rotation $(0.74 \mathrm{~kg} /$ plant). For the nitrogen treatments applied 2 years previously, mean weight of tubers per plant was greatest $(0.83 \mathrm{~kg} / \mathrm{plant})$ from the nil nitrogen treatment, intermediate $(0.76 \mathrm{~kg} / \mathrm{plant})$ from $200 \mathrm{~kg} \mathrm{~N} \mathrm{ha}^{-1}$, and least $(0.73 \mathrm{~kg} / \mathrm{plant})$ from $400 \mathrm{~kg} \mathrm{~N} \mathrm{ha}^{-1}$
( $P=0.008)$. There were no residual effects of the $2006 / 07$ moisture regime treatments on mean tuber yields $(P>0.05$ for the main effect, and interactions involving moisture regime).

Incidence and severity of powdery scab

Figure 3 is a graphic representation depicting the plot to plot variability in severity of powdery scab across the 96 field trial plots. This indicates that the disease was not uniform across the trial, and was more severe in some plots than others.

Powdery scab incidence and severity data are summarised in Fig. 4. Both of these parameters were greatest at the 2007 harvest, for a cultivar ('Ranger Russet') known to be moderately resistant to the disease (Falloon et al. 2003), and progressively less for the two subsequent harvests in 2008 and 2009 , despite the variety grown ('Iwa') being very susceptible to powdery scab.

\section{Agronomic treatment trial (2006/07 growing season)}

Incidence of powdery scab on harvested tubers (Fig. 4a) was affected $(P<0.001)$ by the nitrogen treatments, but not substantially by the moisture regime or crop rotation treatments $(P>0.05$ for all effects involving these factors). Mean
Fig. 3 Mean powdery scab severity scores for potato tubers ('Ranger Russet') harvested in the 2006/07 growing season from 96 field trial plots. Severity is expressed graphically with grey shading, from light (least severe) to dark (most severe). Powdery scab severity scores $(0,1,2$ and 3$)$ are also indicated

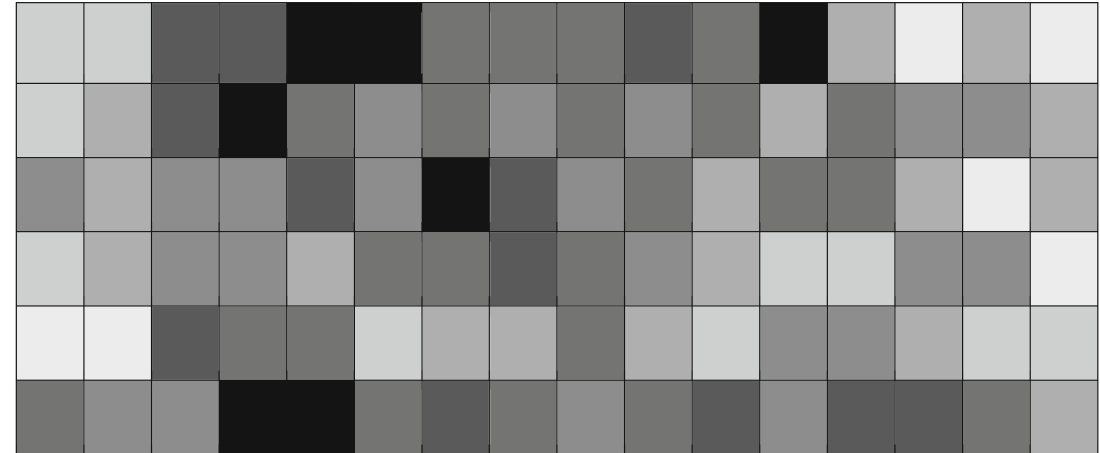

$0.30-0.65$

0.65-1.00

1.00-1.35

1.35-1.70

1.70-2.05

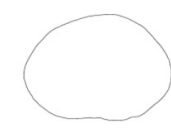

0

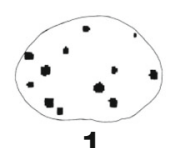

1

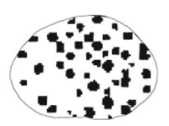

2 
Fig. 4 Mean powdery scab incidence (a) and severity scores (b) for potato tubers harvested in 2007 ('Ranger Russet'), 2008 and 2009 ('Iwa'), from field plots that received different treatments of amounts of nitrogen fertiliser, watering regimes and previous crop rotations during the 2006/07 growing season. $\star$ : optimum watering; •: low watering. Solid lines: potato/pea rotation; dotted lines: potato/wheat rotation. For disease incidence data, bars are $95 \%$ confidence intervals for the smallest and largest values for each harvest, and for severity score data, the bars are LSDs $(P<0.05 ; \mathrm{df}=77)$. Note: the 2008 and 2009 data are presented in relation to nitrogen treatments applied in the 2006/07 season a) Incidence

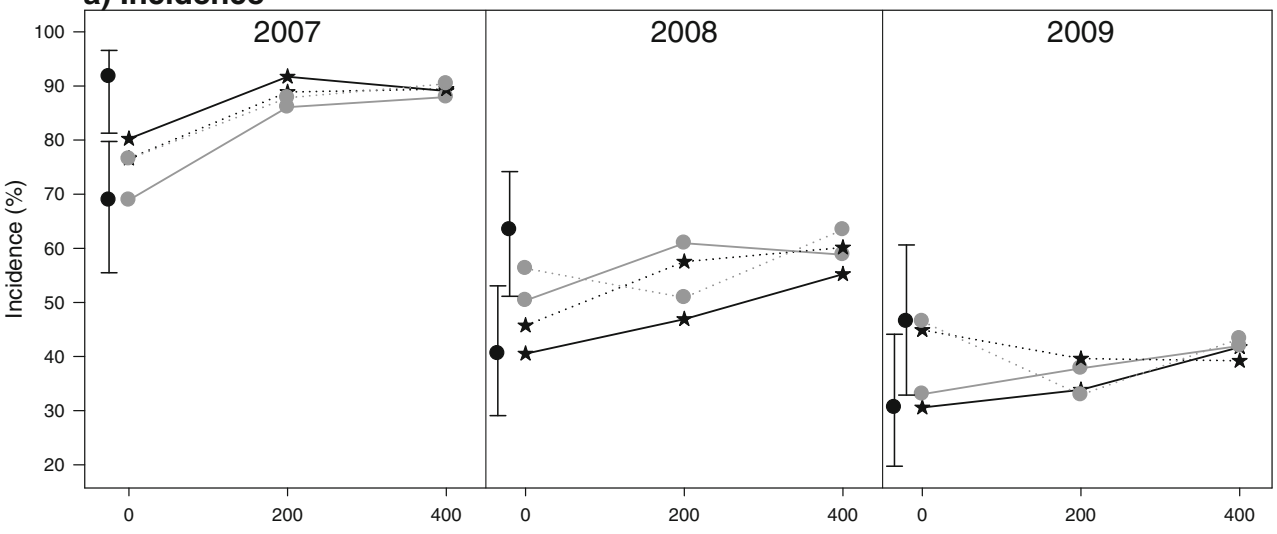

b) Severity score Nitrogen $\left(\mathrm{kg} \mathrm{N} \mathrm{ha}^{-1}\right)$

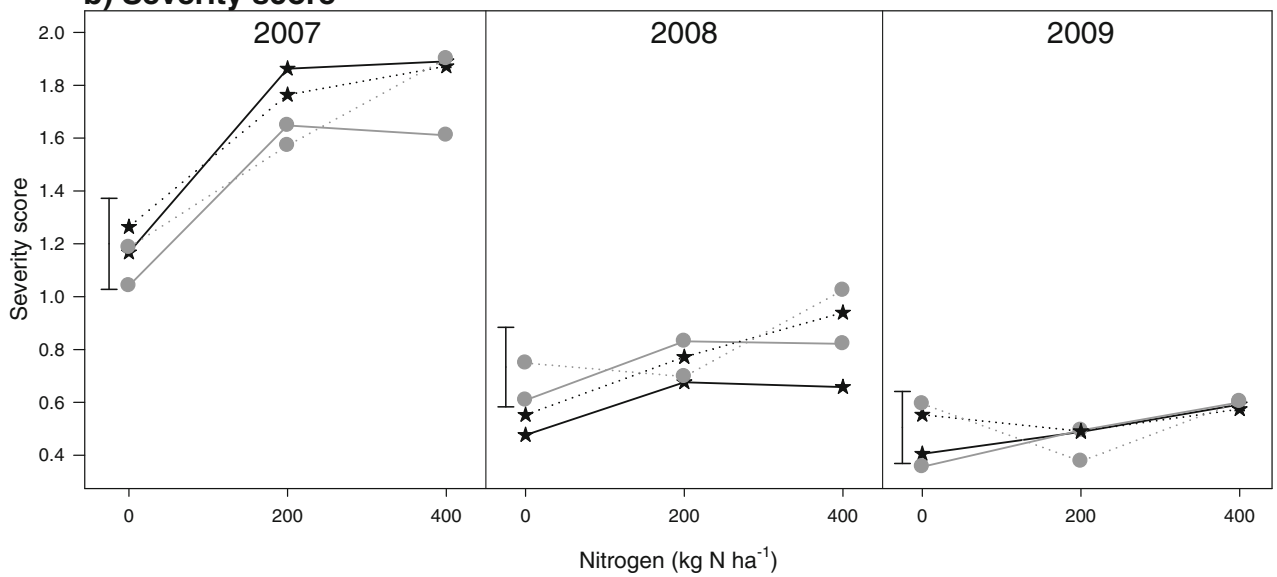

powdery scab incidence was $76 \%$ of tubers infected from the nil nitrogen treatment, and $89 \%$ both from the 200 and $400 \mathrm{~kg} \mathrm{~N} \mathrm{ha}^{-1}$ treatments.

Powdery scab severity (Fig. 4b) was strongly affected by the nitrogen treatments $(P<0.001)$. Mean severity score was 1.16 (equivalent of $7 \%$ of tuber surface area affected) from the nil nitrogen treatment, $1.71(\sim 16 \%$ tuber surface affected $)$ from $200 \mathrm{~kg} \mathrm{~N} \mathrm{ha}^{-1}$ and $1.82(\sim 17 \%$ tuber surface affected) from $400 \mathrm{~kg} \mathrm{~N}^{-1}$. Severity was also affected $(P=0.045)$ by the different moisture regimes. Mean score was $1.49(\sim 12 \%$ tuber surface affected) from the "low" moisture regime and 1.64 ( $\sim 15 \%$ tuber surface affected) from the "optimum" moisture treatment. Powdery scab severity was not affected by the crop rotation treatments $(P>0.3$ for all effects involving rotation).

\section{7/08 growing season}

Incidence and severity of powdery scab (Fig. 4a, b) for tubers harvested in 2008 varied with nitrogen treatments applied one year previously ( $P=0.042$ for incidence; $P=0.003$ for severity). Mean incidences and severity scores were $48 \%$ and 0.60 (equivalent of $3 \%$ of tuber surface affected) from the nil nitrogen treatment, $54 \%$ and 0.74 ( 4\% surface affected) from $200 \mathrm{~kg} \mathrm{~N} \mathrm{ha}^{-1}$, and $59 \%$ and 0.86 ( 4\% surface affected) from $400 \mathrm{~kg} \mathrm{~N} \mathrm{ha}^{-1}$. Incidence and severity of the disease were not strongly affected by the different previous rotation or moisture regime treatments $(P>0.05$ for all effects involving rotation or moisture).

\section{8/09 growing season}

Incidence and severity of powdery scab on tubers harvested in 2009 were not substantially affected by the nitrogen, rotation or moisture regime treatments, applied 2 years previously $(P>0.1$ for all effects).

\section{Spongospora subterranea DNA in soil}

Data of amounts of Spongospora DNA in soil samples taken from the 96 trial plots on five occasions during the three potato growing seasons are summarised in Fig. 5.

\section{Agronomic treatment trial (2006/07 growing season)}

Soil samples taken at the time of tuber harvest in 2007 were assayed for Spongospora DNA. Amounts of pathogen DNA in soil from the different trial plots ranged from 52 to 


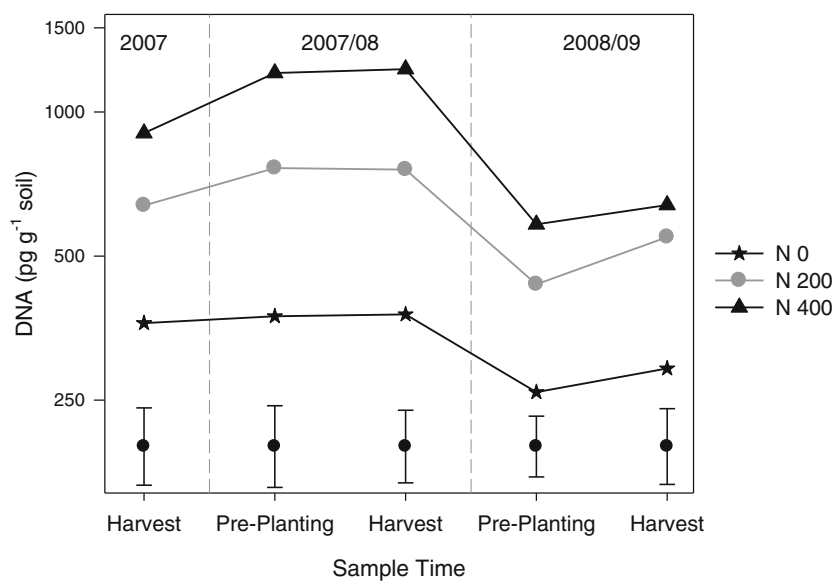

Fig. 5 Mean amounts of Spongospora subterranea DNA in soil sampled on five occasions during three growing seasons $(2006 / 07,2007 / 08$ and 2008/09), from field plots that received different treatments of amounts of nitrogen fertiliser in the 2006/07 season. $\star$ : nil nitrogen; $\bullet: 200 \mathrm{~kg} \mathrm{ha}^{-1}$ nitrogen; $\boldsymbol{\Delta}$ : $400 \mathrm{~kg} \mathrm{ha}^{-1}$ nitrogen. Data are averaged over the different watering regimes and previous crop rotations applied during the 2006/07 growing season. Error bars are $95 \%$ confidence limits for the means at each sampling time. Note: the 2008 and 2009 data are presented in relation to nitrogen treatments applied in the 2006/07 season

3,326 $\mathrm{pg} \mathrm{g}^{-1}$ soil. Mean amounts of DNA (Fig. 5) differed between nitrogen treatments $(P<0.001)$, at $362 \mathrm{pg} \mathrm{g}^{-1}$ soil from the nil nitrogen treatment, $638 \mathrm{pg} \mathrm{g}^{-1}$ from $200 \mathrm{~kg} \mathrm{~N} \mathrm{ha}^{-1}$ and $903 \mathrm{pg} \mathrm{g}^{-1}$ from $400 \mathrm{~kg} \mathrm{~N} \mathrm{ha}^{-1}$. Mean amounts of DNA also differed between the soil moisture regimes $(P=0.02)$, at $674 \mathrm{pg} \mathrm{g}^{-1}$ soil from the "low" soil moisture regime and $522 \mathrm{pg} \mathrm{g}^{-1}$ from the "optimum" regime. Furthermore, soil DNA was affected $(P=0.003)$ by the previous crop rotations. The mean amount of DNA at harvest following the potato/wheat rotation was $699 \mathrm{pg} \mathrm{g}^{-1}$ soil while that following the potato/pea rotation was $503 \mathrm{pg} \mathrm{g}^{-1}$.

\section{7/08 growing season, pre-planting}

Pre-planting amounts of $S$. subterranea DNA in soil taken from the trial plots ranged from 39 to $3,679 \mathrm{pg} \mathrm{g}^{-1}$ soil. Mean amounts of DNA differed with nitrogen treatments $(P<0.001$; Fig. 5), with the magnitude of effect depending on the moisture regime $(P=$ 0.026 for the moisture by nitrogen interaction). On average, soil DNA was $374 \mathrm{pg} \mathrm{g}^{-1}$ soil from the nil nitrogen treatment, $764 \mathrm{pg} \mathrm{g}^{-1}$ from $200 \mathrm{~kg} \mathrm{~N} \mathrm{ha}^{-1}$, and to $1,206 \mathrm{pg} \mathrm{g}^{-1}$ from $400 \mathrm{~kg} \mathrm{~N} \mathrm{ha}^{-1}$. The difference in soil DNA between the 200 and $400 \mathrm{~kg} \mathrm{~N}^{-1}$ treatments was less for the "low" water regime than for the "optimal" regime. Mean amounts of DNA were also affected by the previous crop rotations $(P=0.004)$. The potato/pea (/potato) rotation resulted in a mean of $592 \mathrm{pg} \mathrm{g}^{-1}$ soil while the potato/wheat (/potato) rotation resulted in a mean of $830 \mathrm{pg} \mathrm{g}^{-1}$.
2007/08 growing season, post harvest

Amounts of $S$. subterranea DNA in soil taken from the trial plots at the 2008 harvest (Fig. 5) ranged from 49 to $3,376 \mathrm{pg} \mathrm{g}^{-1}$ soil. Mean amounts of DNA were affected by the amounts nitrogen applied over 15 months previously $(P<0.001)$. Mean soil DNA amounts were very similar to those measured prior to planting ( $378 \mathrm{pg} \mathrm{g}^{-1}$ soil from the nil nitrogen treatment, $758 \mathrm{pg} \mathrm{g}^{-1}$ from $200 \mathrm{~kg} \mathrm{~N} \mathrm{ha}^{-1}$, and $1,229 \mathrm{pg} \mathrm{g}^{-1}$ from the $\left.400 \mathrm{~kg} \mathrm{~N} \mathrm{ha}^{-1}\right)$. The previous crop rotations also affected amounts of pathogen DNA $(P<0.001)$. The potato/wheat (/potato) rotation resulted in a mean of $877 \mathrm{pg} \mathrm{g}^{-1}$ soil compared with $568 \mathrm{pg} \mathrm{g}^{-1}$ for the potato/pea (/potato) rotation. In contrast to the pre-planting result, the previous irrigation regimes had little residual effect on amounts of pathogen DNA in the soil at harvest $(P=0.64$ for the overall effect; $P>0.05$ for all interactions).

\section{8/09 growing season, pre-planting}

There was a general reduction in the amounts of Spongospora DNA in soil during the 6 months between the 2008 harvest and the following tuber planting in spring 2008 (Fig. 5). During this period, the trial site had been planted as a winter crop of annual ryegrass. Nevertheless, the patterns of pathogen DNA in soil were similar to those measured for the previous assay times. DNA levels ranged from 58 to $1,996 \mathrm{pg} \mathrm{g}^{-1}$ soil, and were affected both by the quantities of nitrogen applied more than 2 years previously $(P<0.001)$, and by the previous crop rotations $(P=0.007)$. Mean amounts of DNA were $260 \mathrm{pg} \mathrm{g}^{-1}$ soil from the nil nitrogen treatment, to $436 \mathrm{pg} \mathrm{g}^{-1}$ from $200 \mathrm{~kg} \mathrm{~N} \mathrm{ha}^{-1}$, and $583 \mathrm{pg} \mathrm{g}^{-1}$ from $400 \mathrm{~kg} \mathrm{~N} \mathrm{ha}^{-1}$. The potato/wheat (/potato) previous rotation gave a mean of $455 \mathrm{pg} \mathrm{g}^{-1}$ soil compared to $359 \mathrm{pg} \mathrm{g}^{-1}$ for the potato/pea (/potato) rotation. DNA amounts were unaffected by watering regime $(P=0.49)$. The nitrogen, previous rotation and moisture regime treatment effects were independent of each other ( $P>0.15$ for all interactions).

\section{8/09 growing season, post harvest}

Trends in S. subterranea DNA in soil were again similar to those for the previous harvest, and for those at planting (Fig. 5). DNA amounts ranged from 55 to $2,342 \mathrm{pg} \mathrm{g}^{-1}$ soil, and were affected both by levels of nitrogen applied 2.5 years previously $(P<0.001)$, and the previous crop rotations $(P=$ $0.003)$, but were unaffected by previous moisture regimes $(P=$ $0.59)$. The rotation and nitrogen effects were independent of the other treatment factors ( $P>0.09$ for all interactions). Mean amounts of DNA were $291 \mathrm{pg} \mathrm{g}^{-1}$ soil from the nil nitrogen treatment, $548 \mathrm{pg} \mathrm{g}^{-1}$ from $200 \mathrm{~kg} \mathrm{~N} \mathrm{ha}^{-1}$, and $639 \mathrm{pg} \mathrm{g}^{-1}$ from $400 \mathrm{~kg} \mathrm{~N} \mathrm{ha}^{-1}$. The potato/wheat (/potato/potato) 
previous rotation resulted in a mean of $549 \mathrm{pg} \mathrm{g}^{-1}$, compared with $398 \mathrm{pg} \mathrm{g}^{-1}$ from the potato/pea (/potato/potato) rotation.

\section{Relationships between amounts Spongospora DNA in soil and powdery scab on harvested tubers}

For the 2007 harvest, both powdery scab incidence and severity were only moderately related to the amount of S. subterranea DNA in soil sampled from the trial plots at harvest (Fig. 6). The correlation coefficient (r) for amount of DNA with powdery scab incidence was 0.53 , and 0.63 for amount of DNA with severity of the disease.

In the following two growing seasons (Fig. 7), the amounts of $S$. subterranea DNA in soil at the time of seed tuber planting and powdery scab parameters in harvested tubers were only weakly or not related. For the $2007 / 08$ season, these correlations ( $\mathrm{r}$ ) were 0.48 for powdery scab incidence and 0.46 for severity. For the 2008/09 season, amounts of DNA in soil at planting were not related to either powdery scab incidence

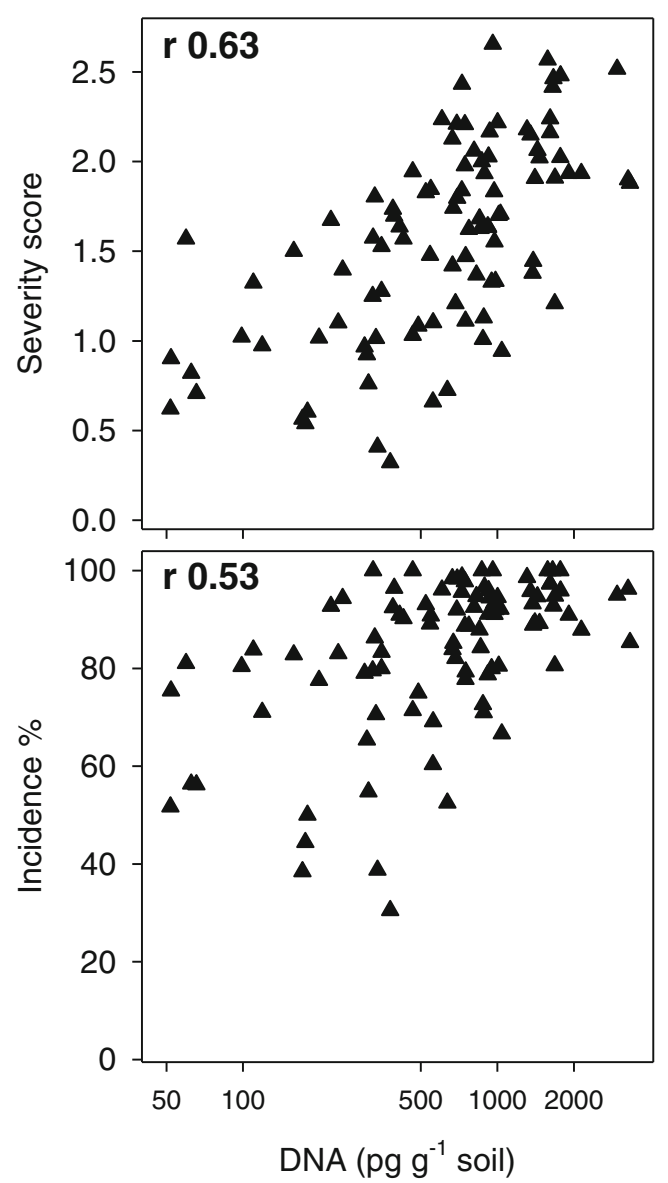

Fig. 6 Relationships between amounts of Spongospora subterranea DNA in soil sampled from 96 field plots at the time of tuber harvest in 2007, and mean powdery scab incidence and severity scores for the harvested tubers. Correlation coefficients (r) are indicated for each relationship $(r=-0.07)$ or severity $(r=-0.02)$ assessed on tubers harvested 5 months later.

\section{Discussion}

It is well recognised that water and nitrogen are generally the agronomic inputs most likely to limit potato yields (e.g. Feibert et al. 1998). The present study has shown that these factors, particularly amounts of nitrogen fertiliser, can also affect the incidence and severity of powdery in potato tubers, and amounts of $S$. subterranea DNA in soil.

The field trial utilised in the present study highlighted the importance of efficiently managing irrigation and nitrogen fertiliser to minimise nitrate leaching from potato crops (Thomas et al. 2012). The nitrogen application rates used in the trial spanned rates used for normal potato production (approx. $300 \mathrm{~kg} \mathrm{~N} \mathrm{ha}^{-1}$; Jamieson et al. 2006). The trial showed that nitrate leaching losses from potatoes managed to maintain soil moisture deficits of at least $30 \mathrm{~mm}$ were three to nine times less than when the soil was maintained at much higher moisture content (Thomas et al. 2012). Excess nitrogen and excess irrigation, at amounts greater than plant requirements, have no productive benefits, and may result in nitrate contamination of groundwater.

The trial provided a field site where different amounts of powdery scab were detected on tubers harvested from plots that had been subjected to different agronomic practices (nitrate fertiliser, irrigation, previous crop regimes). Only slight effects were recorded of soil moisture and previous cropping history on the disease. This was probably because rainfall during crop growth was regular so soil moisture contents in both the "optimum" and "low" moisture treatments remained similar. The two previous cropping histories were used to measure any effects that deep rooting (wheat) or shallow root (pea) crops may have on nitrate leaching from soil, and were not chosen for any perceived effects on soilborne diseases of potato.

The potato cultivar 'Ranger Russet' is classified as moderately resistant to powdery scab (Falloon et al. 2003), but high incidence and light to moderate severity of the disease (equivalent to $2 \%$, and up to $36 \%$ of tuber surface area affected) were recorded on tubers of this cultivar in the trial. Even very low incidence of powdery scab in seed potato tuber lines causes them to be rejected from seed certification, while more severe infections cause tuber quality problems for processing potatoes and washed tubers for fresh market sale.

Results from the powdery scab assessments suggest that the soil in some of the plots was heavily infested with S. subterranea. This was confirmed by the large amounts of Spongospora DNA detected in soil samples taken from many of the trial plots at tuber first harvest (2007). Powdery scab 
Fig. 7 Relationships between amounts of Spongospora subterranea DNA in soil sampled from 96 field plots prior to potato planting and mean powdery scab incidence and severity scores in potato tubers harvested from the plots, for two growing seasons (2007/08 and 2008/09).

Correlation coefficients (r) are indicated for each relationship

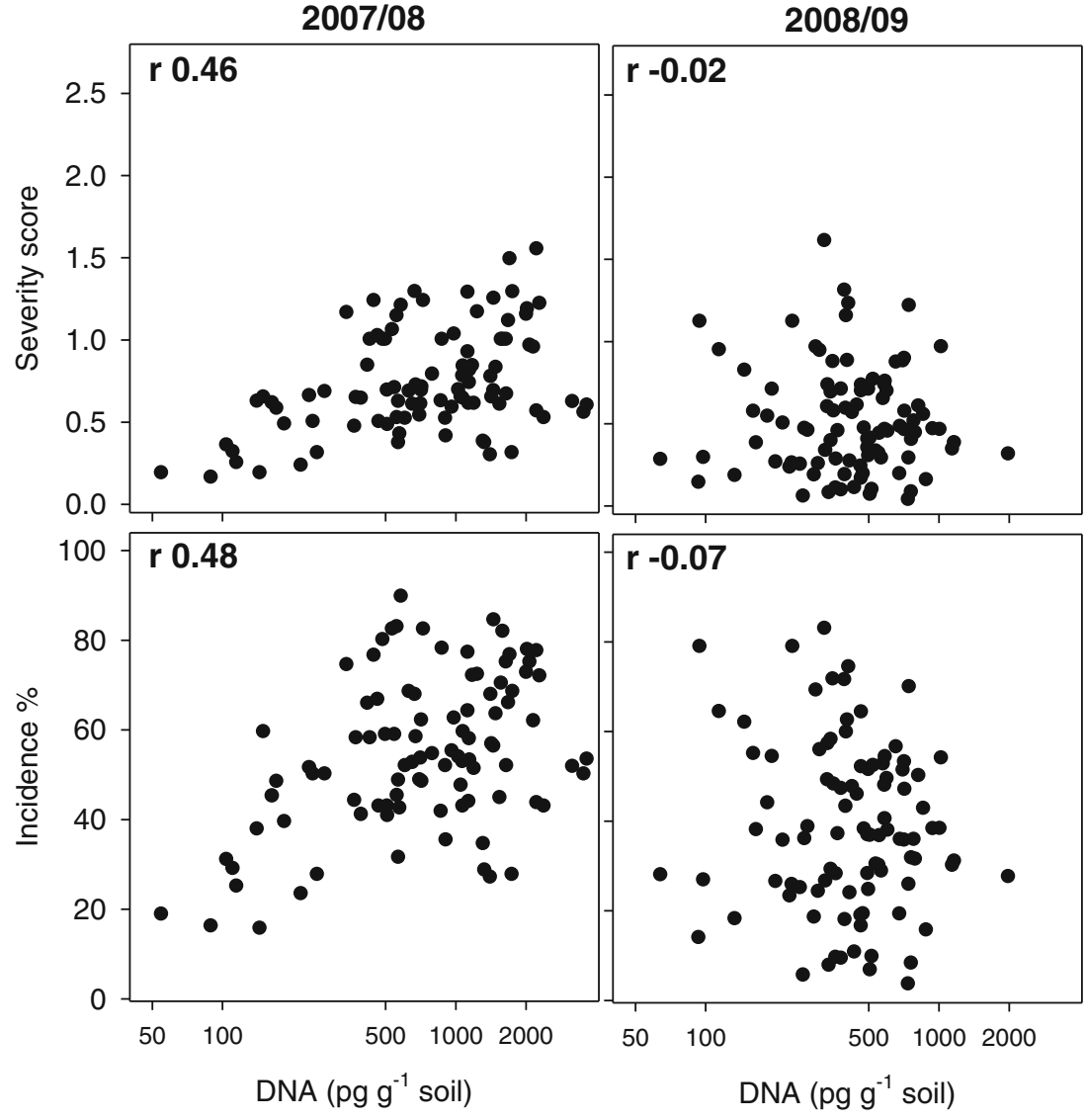

was not evenly distributed across the trial site (Fig. 3), and some of the unevenness was due to the different agronomic treatments applied in the trial.

Huber and Thompson (2007) reviewed information on effects of nitrogen on plant diseases. For most pathosystems and conditions, nitrogen is generally associated with increased disease. However, effects of rate and time of application, as well as soil conditions and interactions with other soil nutrients, may influence this generality, and nitrogen applications reduce diseases in some cases. Furthermore, different pathogens respond differently to different forms of nitrogen (ammonium or nitrate). For example, Shah et al. (2004) found that the severity of early blight of potato (caused by Alternaria solani) was greater following high rates of nitrogen fertiliser application (urea) than after low application rates. More specifically, the results of Tuncer (2002) indicated that severity of powdery scab on potato tubers was greater where high rates of nitrogen were applied than when low rates were used, although the form of nitrogen applied was not specified in this report. Applications of urea fertiliser at high rates have been shown to reduce powdery scab severity in field soil heavily infested with $S$. subterranea, and growers sometimes apply urea as a powdery scab control strategy (Dr NS Crump, personal communication). Falloon et al. (2009) demonstrated in a glasshouse experiment that nitrate nitrogen had little effect on intensity of $S$. subterranea potato root hyperplasia (numbers of root galls), while ammonium nitrogen reduced severity of this stage of the pathogen cycle. Ammonium and nitrate nitrogen together (as ammonium nitrate) gave intermediate amounts of root hyperplasia.

Nitrate and ammonium nitrogen were applied in the field trial described in the present study, and high rates of this fertiliser increased incidence and severity of powdery scab on harvested tubers. Increased growth of host plants, particularly of roots, would provide greater amounts of host tissue available for proliferation of $S$. subterranea through the zoospore multiplication and root infection cycles. Furthermore, reduced cellulose content of root or stolon (tuber) cell walls after excess nitrogen application may have increased host susceptibility to infection (zoospore penetration of epidermis cells). This mechanism has been postulated to explain increased host susceptibility to other root pathogens (Huber and Thompson 2007). Optimum amounts of nitrogen would increase the duration of tuber development, and may increase susceptibility of stolons/tubers to $S$. subterranea. Monitoring of the amounts of $S$. subterranea DNA in soil in the present study indicated that inoculum of the pathogen was greatest where the nitrogen fertiliser had been previously applied, and this effect continued for two subsequent growing seasons (see below). 
It is generally accepted that moist soils favour development of powdery scab, probably providing good conditions for $S$. subterranea resting spore germination, zoospore movement and infection of host roots and tubers (Merz and Falloon 2010). In the present study, the "optimal" moisture regime gave increased severity of powdery scab in tubers harvested in 2007, suggesting that this treatment probably provided more favourable conditions for tuber infection in comparison with the "low" moisture regime. The amounts of S. subterranea DNA detected in soil did not reflect this irrigation effect on increased powdery scab severity. The irrigation regimes did not affect powdery scab incidence, however, with a similar proportion of tubers affected from both irrigation treatments. The high summer rainfall experienced during the 2006/07 growing season, and the regular irrigation treatments, probably maintained sufficient soil moisture at the trial site for general dispersal of the pathogen to tuber initials (the likely stage of tuber development when infection occurs). However, the "optimal" regime probably provided better conditions for powdery scab development on the growing tubers in mid- and late summer, giving greater severity of tuber disease than occurred with the "low" moisture regime.

Different crop rotations also may affect soilborne diseases of potato, as has been demonstrated by Larkin et al. (2010) in a long-term study. Some previous crops (Brassica spp.) reduced three important diseases, while others had little or no disease reducing effects. In the present study, potatoes followed by wheat before replanting potatoes resulted in more powdery scab than when peas were used as the break crop in the rotation. This suggests possible small direct or indirect effects of the legume crop on S. subterranea, although the mechanisms for this are unclear. Larkin et al. (2010) reported that legumes (green bean or soybean) in rotations had no positive benefits related to the soilborne diseases they monitored (Rhizoctonia canker, black scurf, common scab, Verticillium wilt).

In the present study, different winter break crops were grown between potato plantings in the two growing seasons, where amounts of $S$. subterranea DNA in soil and powdery scab incidence and severity were assessed in harvested potatoes. These assays indicated that there was little effect on the pathogen from the winter wheat crop, but a year later the annual ryegrass winter crop reduced amounts of pathogen DNA in soil. This reduction was general across all of the previous agronomic treatments applied in 2006/07 and coincided with a general reduction in powdery scab on tubers harvested from the trial plots, suggesting that annual ryegrass may have some powdery scab mitigation effects. This may have been due to greater amounts of soil organic matter following the winter wheat crop, which was incorporated, than after ryegrass, which was removed. However, these effects need to be verified in further field research.

Assays of pathogen DNA in soil have been suggested as possible predictors of soilborne diseases (Ophel-Keller et al. 2008), including powdery scab of potato (van der Graaf et al. 2003), particularly to indicate levels of risk posed by individual pathogens. The present study has investigated the use of assays of S. subterranea DNA in soil to predict powdery scab on tubers, utilising a field trial where the soil had widely different amounts of DNA of the pathogen, and where different amounts of powdery scab incidence and severity had been identified in discrete plots.

A weak relationship was observed between amounts of $S$. subterranea DNA in soil collected after harvest and the amounts (incidence and severity) of powdery scab on tubers from plots with different agronomic treatments in the 2006/07 season. DNA analysis of soil probably detects the pathogen as resting spores (in sporosori) contaminating field soil. The positive relationship between soil DNA and powdery scab detected at this harvest probably reflects escape of sporosori of the pathogen into the soil, either from root galls on the plants grown in the plots, or from lesions on the tubers. The different treatments applied in the trial probably gave different amounts of root galling, definitely gave measurably different amounts of powdery scab on tubers, and probably resulted in different quantities of sporosorus inoculum released into the soil, to be detected as soil DNA of the pathogen. This explains why incidence and severity of powdery scab on harvested tubers was related to amounts of DNA in the soil samples collected at that time.

Shah et al. (2012) have demonstrated that even low amounts of the pathogen in soil can adversely affect growth of potato plants and tuber yields. This indicates that the consequences of $S$. subterranea infections are likely to be greater than reductions in tuber quality, and may cause tuber yield depression in affected crops.

The assays of soil in the two subsequent growing seasons gave poor relationship (2007/08 season) and no relationship (2008/09) between amounts of $S$. subterranea DNA at the time of planting and incidence and severity of powdery scab in the potato tubers from the respective following harvests. This was in spite of the use of a potato cultivar ('Iwa') known to be very susceptible to the disease (Falloon et al. 2003), and maintaining moist soil conditions at the trial site using regular irrigation applications. In both of these growing seasons there were large amounts of DNA in soil sampled before seed tuber planting from some of the trial plots (approx. 2,000$3,000 \mathrm{pg} \mathrm{g}^{-1}$ soil), and small amounts (40-50 $\mathrm{pg} \mathrm{g}^{-1}$ soil) from others. However, these differences were not well reflected in the amounts of powdery scab that developed 
on the tubers harvested from the plots about 5 months later. This indicates that environmental conditions applying in the 2007/08 and 2008/09 growing seasons were not as conducive to development of the disease as in 2006/07.

The life cycle of $S$. subterranea has been described and illustrated elsewhere (Kole 1954; Karling 1968; Harrison et al. 1997; Merz 2008). The pathogen is polycyclic, firstly producing 'primary' zoospores from sporosori contaminating soil. These zoospores infect below-ground host tissues, and many zoosporangia develop in host root cells soon after primary infection. Multiple cycles of zoospores are then produced from zoosporangia, and these infect root and stolon tissues, eventually causing lesions on host tubers (powdery scab). Reports of relationships between amounts of sporosorus inoculum in soil and Spongospora root and tuber diseases have given varied estimates of inoculum amounts required to give severe disease (Merz 1993; Qu et al. 2006; Nakayama et al. 2007; van der Graaf et al. 2005). It is generally accepted that small amounts of sporosorus inoculum can result in heavy root and tuber infection if environmental conditions are suitable, and susceptible hosts are grown in association with sporosorus inoculum (Merz 1989; van der Graaf et al. 2005, 2007; Shah et al. 2012). A further consideration is that sporosori contain variable numbers of resting spores (from 18 to 2,700: Falloon et al. 2011), so using numbers of sporosori as a basis for estimating inoculum potential could incorrectly estimate the amounts of resting spore inoculum by more than three orders of magnitude.

The agronomic field trial outlined here has demonstrated that agronomic treatments (particularly use of nitrogen fertiliser) can increase incidence and severity of powdery scab of potatoes. Furthermore, plots treated with nitrogen fertiliser in 2006/07 maintained large amounts of $S$. subterranea DNA in soil during the two subsequent growing seasons. It is possible that use of nitrogen fertilisers based solely on ammonium compounds (Falloon et al. 2009) may be advisable where Spongospora diseases are likely to occur. This could be in fields with histories of these diseases and/or where the potato cultivars grown are known to be susceptible. The results from subsequent monitoring of pre-planting S. subterranea DNA in soil and powdery scab in harvested potatoes, over two growing seasons, have indicated that using DNA technology as a disease prediction tool may have limited application in the practical management of Spongospora diseases of potato.

Acknowledgments This research was funded by the New Zealand Ministry of Business, Innovation and Employment, through the "Ecosystems Bioprection" Programme (LINX0804). Measurements of Spongospora DNA in soil samples were carried out by the South Australian Research \& Development Institute, Urrbrae, Australia, under the auspices of the Australian Potato Research Programme (APRP1), funded through grower levies and Horticulture Australia Ltd.

\section{References}

Committee GS (2008) The Guide to GenStat Release 11 - Part2: Statistics. VSN International, Oxford

Falloon RE, Viljanen-Rollinson SLH, Coles GD, Poff JD (1995) Disease severity keys for powdery and downy mildews of pea and powdery scab of potato. N Z J Crop Hortic Sci 23:31-37

Falloon RE, Genet RA, Wallace AR, Butler RC (2003) Susceptibility of potato (Solanum tuberosum) cultivars to powdery scab (caused by Spongospora subterranea f. sp. subterranea), and relationships between tuber and root infection. Australas Plant Pathol 32:377-385

Falloon RE, Curtin D, Lister RA, Butler RC, Scott CL, Crump NS (2009) Nitrogen form affects Spongospora subterranea infection of potato roots. Conference Handbook, APPS2009 (17th Australasian Plant Pathology Conference), 29 September - 1 October 2009, Newcastle, Australia: 147

Falloon RE, Merz U, Lister RA, Wallace AR, Hayes SP (2011) Morphological enumeration of resting spores in sporosori of the plant pathogen Spongospora subterranea. Acta Protozool 50:121132

Feibert EBG, Shock CC, Saunders LD (1998) Nitrogen fertilizer requirements of potatoes using carefully scheduled sprinkler irrigation. HortSci 33:262-265

Harrison JG, Searle RJ, Williams NA (1997) Powdery scab disease of potato - a review. Plant Pathol 46:1-25

Huber DM, Thompson IA (2007) Nitrogen and plant disease. In Mineral nutrition and plant disease. Eds LE Datnoff, WH Elmer \& DM Huber. The American Phytopathological Society, St Paul, Minnesota, USA: $31-44$.

Jamieson PD, Zyskowski RF, Sinton SM, Brown HE, Butler RC (2006) The potato calculator: a tool for scheduling nitrogen fertilizer applications. Agron New Zealand 36:49-53

Karling JS (1968) The Plasmiodiophorales. Hafner Publishing Company, New York, pp 183-184

Kirk HG (2008) Mop-top virus, relationship to its vector. Am J Potato Res $85: 261-265$

Kole AP (1954) A contribution to the knowledge of Spongospora subterranea (Wallr.) Lagerh., the cause of powdery scab of potatoes. Tijdschrift over Plantenziekten 60:1-65

Larkin RP, Griffin TS, Honeycutt CW (2010) Rotation and cover crop effects on soilborne potato diseases, tuber yield and soil microbial communities. Plant Dis 94:1491-1502

McCullagh P, Nelder JA (1989) Generalised linear models. Chapman \& Hall, London: $x i x+511$ pp.

Merz U (1989) Infectivity, inoculum density and germination of Spongospora subterranea resting spores : a solution-culture test system. EPPO Bull 19:585-592

Merz U (1993) Epidemiological aspects of powdery scab of potatoes caused by Spongospora subterranea. In: Hiruki C (ed) Proceedings of the 2nd Symposium of the International Working Group on Plant Viruses with Fungal Vectors. Montreal, Canada, pp 104-106

Merz U (2008) Powdery scab of potato - occurrence, life cycle and epidemiology. Am J Potato Res 85:241-246

Merz U, Falloon RE (2010) Review: powdery scab of potato - increased knowledge of pathogen biology and disease epidemiology for effective disease management. Potato Res 52:17-37

Nakayama T, Horito M, Shimanuki T (2007) Spongospora subterranea soil contamination and its relationship to severity of powdery scab of potato. J Gen Plant Pathol 73:229-234

Ophel-Keller K, McKay A, Hartley D, Herdina CJ (2008) Development of a routine DNA-based testing service for soilborne diseases in Australia. Australas Plant Pathol 37:243-253

Payne R, Welham S, Harding S (2012) A guide to REML in GenStat (15th edition). VSN International, Oxford, $94 \mathrm{pp}$ 
Qu XS, Kavanagh JA, Egan D, Christ BJ (2006) Detection and quantification of Spongospora subterranea f. sp. subterranea by PCR in hoist tissue and naturally instead soil. Am J Potato Res 83:21-30

Shah FA, McKenzie BA, Gaunt RE, Marshall JW, Frampton CM (2004) Effect of early blight (Alternaria solani) on healthy area duration and healthy area absorption of potatoes (Solanum tuberosum) grown in Canterbury, New Zealand with different nitrogen application and stress from potato cyst nematode (Globodera rostochiensis). N Z J Crop Hortic Sci 32:85-102

Shah FA, Falloon RE, Butler RC, Lister RA (2012) Low amounts of Spongospora subterranea sporosorus inoculum cause severe powdery scab, root galling and reduced water use in potato (Solanum tuberosum). Australas Plant Pathol 41:219-228

Thomas SM, Francis GS, Waterland HE, Zyskowski RF, Tabley FJ, Gillespie RN, Sharp JM, Fraser PM (2012) Irrigation and nitrogen fertiliser management effects on nitrate leaching losses from crop rotations. In: Richards KG, Fenton O, Watson CJ (eds) Proceedings of the 17th International Nitrogen Workshop - Innovations for sustainable use of nitrogen resources. Wexford, Ireland, pp 333-334

Tuncer G (2002) The effect of irrigation and nitrogen on powdery scab and yield of potatoes. Potato Res 45:153-161

van der Graaf P, Lees AK, Cullen DW, Duncan JM (2003) Detection and quantification of Spongospora subterranea in soil, water and plant tissue samples using real-time PCR. Eur J Plant Pathol 109:589-597

van der Graaf P, Lees AK, Wale SJ, Duncan JM (2005) Effect of soil inoculum level and environmental factors on potato powdery scab caused by Spongospora subterranea. Plant Pathol 54:22-38

van der Graaf P, Wale SJ, Lees AK (2007) Factors affecting the incidence and severity of Spongospora subterranea infection and galling in potato roots. Plant Pathol 56:1005-1013 